\title{
Pemanfaatan marketplace tokopedia untuk pengembangan usaha dalam meningkatkan perekonomian di tengah dampak pandemi covid-19
}

\author{
Brahmantya Aji Pramudita ${ }^{1 *}$, Muhammad Hablul Barri ${ }^{2}$, Wahmisari \\ Priharti $^{3}$, Achmad Rizal $^{4}$, Novi Prihatiningrum ${ }^{5}$, Iswahyudi Hidayat ${ }^{6}$ \\ ${ }^{1}$ Telkom University, Bandung, Indonesia, email: brahmantyaajip@telkomuniversity.ac.id \\ 2Telkom University, Bandung, Indonesia, email: mhbarri@telkomuniversity.ac.id \\ ${ }^{3}$ Telkom University, Bandung, Indonesia, email: wpriharti@telkomuniversity.ac.id \\ ${ }^{4}$ Telkom University, Bandung, Indonesia, email: achmadrizal@telkomuniversity.ac.id \\ 5Telkom University, Bandung, Indonesia, email: nprihatiningrum@telkomuniversity.ac.id \\ 6Telkom University, Bandung, Indonesia, email: iswahyudihidayat@telkomuniversity.ac.id \\ *Koresponden penulis
}

\section{Info Artikel}

Diajukan: 2021-07-16

Diterima: 2022-01-01

Diterbitkan: 2022-01-17

Keywords:

covid-19; economic; pandemic; marketplace; online; tokopedia

Kata Kunci:

covid-19; ekonomi; pandemi; marketplace; daring; tokopedia

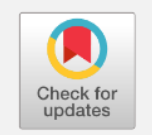

\section{(1) (2)}

Lisensi: cc-by-sa

Copyright $\odot 2022$ Brahmantya Aji Pramudita, Muhammad Hablul Barri, Wahmisari Priharti, Achmad Rizal, Novi Prihatiningrum, Iswahyudi Hidayat

\begin{abstract}
The impact of the Covid-19 pandemic on the Indonesian people is extraordinary. The government limiting community activities resulted in the worst economic sector due to reduced buying and selling transactions. Therefore, Micro, Small, and Medium Enterprises (MSMEs) experienced a massive decline in economic activity. The digital platform is a solution and a way to maintain and grow a business. In Indonesia, there are many choices of marketplaces that can increase business. Various products can be marketed through the marketplace. In addition, the marketplace has the advantage of marketing products because it has an extensive network. Therefore, socialization and training using digital platforms are vital to deal with this Covid-19 pandemic. The target community, members of the AlFitroh mosque management, have a high school (SMA) education background and have not yet found a job, but they still need business skills to deal with the pandemic. Therefore, utilizing the Tokopedia marketplace requires business training to increase and maintain economic power during or outside the pandemic. The survey results show that participants benefit from this training and are interested in building a business or developing a business online. So, participants can adapt to the conditions of the Covid-19 pandemic, which cannot sell typically. In addition, this training can produce new entrepreneurs.
\end{abstract}

\section{Abstrak}

Dampak pandemi Covid-19 bagi masyarakat Indonesia sangat luar biasa. Kebijakan pemerintah dalam membatasi kegiatan masyarakat mengakibatkan sektor ekonomi usaha mikro menjadi sektor paling terpuruk karena berkurangnya transaksi jual beli. Akibatnya, Usaha Mikro, Kecil, dan Menengah (UMKM) mengalami penurunan besar pada kegiatan ekonomi. Platform digital merupakan solusi dan cara dalam mempertahankan dan mengembangkan usaha. Di Indonesia sudah banyak pilihan marketplace yang dapat digunakan untuk meningkatkan usaha. Berbagai produk dapat dipasarkan melalui marketplace. Selain itu, marketplace memiliki keuntungan dalam memasarkan produk karena memiliki jaringan yang sangat luas. Oleh karena itu, sosialisasi dan pelatihan memanfaatkan platform digital sangat diperlukan untuk menghadapi pandemi Covid-19 ini. Masyarakat sasar anggota pemuda pengurus masjid Al-Fitroh 
memiliki latar belakang pendidikan Sekolah Menengah Akhir (SMA) dan belum mendapatkan pekerjaan tetap membutuhkan keahlian usaha untuk menghadapi pandemi. Oleh karena itu, pelatihan usaha dengan memanfaatkan marketplace Tokopedia diperlukan untuk meningkatkan dan mempertahankan daya ekonomi di masa pandemi atau di luar masa pandemi. Hasil dari survei menunjukkan bahwa peserta mendapatkan manfaat dari pelatihan ini dan memiliki ketertarikan untuk membangun usaha atau mengembangkan usaha secara online. Sehingga, peserta dapat beradaptasi dengan kondisi pandemi Covid-19 ini yang tidak bisa berjualan secara normal. Selain itu, pelatihan ini memiliki potensi untuk menghasilkan pengusaha baru.

\section{Cara mensitasi artikel:}

Pramudita, B. A., Barri, M. H., Priharti, W., Rizal, A., Prihatiningrum, N., \& Hidayat, I. (2022). Pemanfaatan marketplace tokopedia untuk pengembangan usaha dalam meningkatkan perekonomian di tengah dampak pandemi covid-19. Jurnal Inovasi Hasil Pengabdian Masyarakat (JIPEMAS), 5(1), 80-91. https://doi.org/10.33474/jipemas.v5i1.11694

\section{PENDAHULUAN}

Dampak akibat pandemi Covid-19 sangat luar biasa terhadap kehidupan manusia dan mengubah pola kegiatan manusia. Sektor ekonomi merupakan sektor yang paling terpengaruh akibat dampak dari pandemi. Semenjak pandemi Covid-19 masuk ke Indonesia dan diumumkan resmi oleh pemerintah di bulan Maret 2020, banyak sektor Usaha Mikro, Kecil dan Menengah (UMKM) mulai terdampak dan menurunkan aktivitas perekonomian. Selain itu, pembatasan kegiatan yang diberlakukan oleh pemerintah untuk mengurangi dampak pandemi memperparah situasi perekonomian. Padahal, UMKM memiliki peran utama dan penting bagi perkembangan ekonomi Nasional dan penyerapan tenaga kerja (Azizah et al., 2020; Istiatin \& Marwati, 2021). Oleh karena itu, banyak UMKM yang tidak beroperasi, menurunkan kapasitas produksi, hingga menutup usaha karena turunnya penjualan, modal yang berkurang, dan distribusi yang terganggu (Arrizal \& Sofyantoro, 2020; Rosita, 2020).

Berbagai cara dilakukan oleh pengusaha UMKM untuk mempertahankan bisnis mereka. Salah satu cara yang dilakukan adalah memangkas jumlah pegawai. Pemangkasan jumlah pegawai memang merupakan pilihan yang buruk. Oleh karena itu, pandemi Covid-19 menyebabkan bertambahnya jumlah pengangguran. Jumlah pengangguran yang bertambah mengakibatkan perekonomian menurun dan menimbulkan ketidakstabilan sosial, politik, dan pemicu terjadinya kriminalitas (Jalil et al., 2020). Keadaan bertambah buruk ketika jumlah pengangguran bertambah banyak karena adanya lulusan baru dari tingkat Sekolah Menengah Akhir (SMA) dan perguruan tinggi. Kondisi jumlah lapangan kerja yang berkurang di masa pandemu dan pertambahan jumlah pengangguran tersebut perlu dicarikan solusi agar tidak memperparah dampak dari pandemi Covid-19.

Pada era revolusi industri 4.0, platform digital merupakan solusi dan cara yang dapat digunakan untuk memulai, mempertahankan, dan mengembangkan usaha (Awali, 2020; Perdamaian et al., 2020; Zebua \& Sunaryanto, 2021). Platform digital yang digunakan untuk memulai usaha adalah layanan marketplace. Di Indonesia sudah banyak pilihan marketplace yang dapat digunakan untuk memulai dan meningkatkan usaha. Melalui marketplace, 
berbagai produk dapat dipasarkan, seperti hasil pertanian (Zebua \& Sunaryanto, 2021), makanan dan minuman (Diana \& Laila, 2020; Mubarrok et al., 2021), hasil kerajinan (Desiani et al., 2021), dll. Selain itu, marketplace memiliki keuntungan dalam memasarkan produk karena memiliki jaringan yang sangat luas. Penjualan dan pemasaran barang merupakan beberapa keuntungan dari marketplace yang didapat untuk dimanfaatkan oleh pengusaha baru memulai usaha. Peluang tersebut dapat digunakan oleh karyawan atau pegawai yang terkena pemutusan kerja dan lulusan SMA dan perguruan tinggi untuk menunggu dibukanya kembali lapangan kerja. Oleh karena itu, sosialisasi dan pelatihan memanfaatkan platform digital sangat penting dan krusial di masa pandemi ini. Sosialisasi dan pelatihan tersebut dapat memberikan peluang usaha untuk memulia dan berkembang (Kala'lembang, 2017) dan merupakan strategi untuk meningkatkan serta memulihkan perekonomian UMKM selama pandemi Covid-19 (Azizah et al., 2020; Barri et al., 2021; Taryudi et al., 2021).

Ikatan pemuda Masjid Al-Fitroh sebagai mitra sasar merupakan bagian dari unit-unit yang berada dalam struktur organisasi Dewan Kemakmuran Masjid (DKM) Al-Fitroh Komplek Griya Prima Asri. Masjid Al-Fitroh merupakan masjid besar komplek yang berlokasi di Desa Bojongmalaka, Kecamatan Baleendah, Kabupaten Bandung. Masjid dengan kapasitas jemaah sekitar 2000 orang saat ini menjadi pusat kegiatan warga untuk beribadah dan melakukan interaksi sosial. Berdasarkan kondisi tersebut, maka masjid sebagai sentral pengembangan dan pemberdayaan mengambil satu peran penting yaitu mengembangan sayap dakwah dan pengembangan sumber daya manusia dengan target pemuda dan remaja. Ikatan Pemuda Masjid Al-Fitroh merupakan pilihan positif dalam rangka pembinaan remaja khususnya di komplek Griya Prima Asri, karena tanpa mengurangi ciri khas remaja untuk berkreasi dan berkarya, organisasi remaja masjid memberikan wadah yang positif yaitu kreatifitas dengan tetap menjunjung nilai-nilai agama sebagai penggerak semua aktivitas tersebut.

Ikatan pemuda Al-Fitroh sendiri memiliki sekitar 70 anggota dengan 40 anggota yang sangat aktif dalam setiap kegiatan yang diselenggarakan. Oleh karena itu, dalam konteks penyiapan kemandirian dan kesiapan sebagai penerus mereka mesti punya kemampuan berdikari secara ekonomi. Namun, sebagian besar anggota memiliki latar belakang tingkat SMA dan sederajat serta perguruan tinggi. Pada masa pandemi Covid-19, kegiatan pemuda masjid Al-Fitroh menjadi terbatas. Selain itu, kebanyakan dari mereka merupakan lulusan baru dari SMA dan perguruan tinggi. Sehingga, banyak anggota pemuda yang belum memiliki pekerjaan atau rencana berikutnya karena sedikitnya lowongan pekerjaan akibat dampak dari pandemi. Oleh karena itu, ikatan pemuda Al-Fitroh dipilih sebagai masyarakat sasar untuk mewujudkan visi kemandirian yang menjadi salah satu visi seksi kepemudaan. Selain itu pemuda dinilai pengurus DKM lebih kreatif dalam menghadapi setiap permasalahan yang muncul. Sehingga dengan target sasar para pemuda AlFitroh diharapkan akan memberikan dampak yang lebih luas, tidak hanya pada masyarakat sekitar lingkungan masjid, tetapi masyarakat yang membutuhkan secara umum. Pemuda masjid Al-Fitroh juga sangat terbuka dalam menjalin 
kerjasama antar organisasi kepemudaan seperti karang taruna, sehingga diharapkan program ini nantinya dapat berjalan secara berkelanjutan dan meberikan dampak positif bagi setiap kalangan.

Pelatihan pembekalan keahlian dalam berjualan daring sangat penting dilakukan karena memberikan kegiatan yang mengembangkan keahlian dan memberikan pengetahuan bagi pengurus masjid cara berjualan daring. Sehingga, pengurus masjid yang umumnya generasi milenial memperoleh kegiatan yang positif, bermanfaat, mendapatkan penghasilan sendiri, meningkatkan dan mempertahankan daya ekonomi di masa pandemi atau di luar masa pandemi.

\section{METODE PELAKSANAAN}

Pelaksanaan kegiatan pengabdian masyarakat ini diawali dari minat dan permintaan dari masyarakat di Griya Prima Asri (GPA), terutama masyarakat sasar pengurus Masjid Al-Fitroh, yang ingin membangun dan mengembangkan usaha dengan menggunakan marketplace. Pelaksanaan kegiatan dilaksanakan selama 1 hari yaitu pada tanggal 15 Maret 2021. Urutan pelaksanaan kegiatan pelatihan ditunjukkan pada Gambar 1.

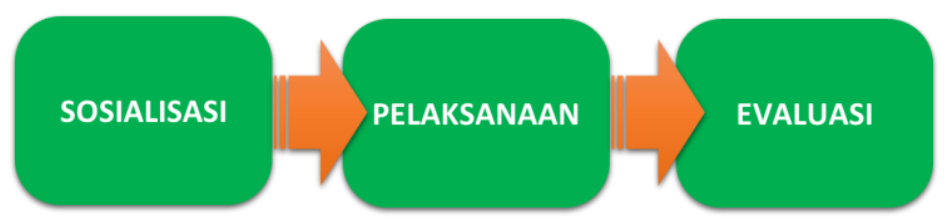

Gambar 1. Alur metode pelaksanaan kegiatan pelatihan

Proses pelaksanaan kegiatan pelatihan ini dilakukan dengan proses community development. Proses community development digunakan pada kegiatan pengabdian masyarakat ini untuk membangun dan memperbaiki kehidupan dan ekonomi akibat dampak pandemi Covid-19. Tim pengabdian masyarakat membantu untuk memberikan bantuan teknis yang dibutuhkan masyarakat. Pada Gambar 1 menunjukkan alur pelaksanaan pelatihan yang digunakan di pengabdian masyrakat dengan membagi kegiatan menjadi 3, yaitu sosialisasi, pelaksanaan, dan evaluasi.

Kegiatan sosialisasi dilakukan untuk menyambung permintaan dari masyarakat sasar. Perencanaan dan koordinasi dilakukan untuk menentukan tempat dan waktu pelaksanaan kegiatan pelatihan. Selain itu, kegiatan sosialisasi ini dilakukan untuk memperoleh masalah yang dihadapi oleh masyarakat sasar dengan melakukan diskusi dan wawancara. Selanjutnya, pelaksanaan kegiatan dilakukan dengan model pelatihan. Pelatihan dilakukan dengan metode ceramah, diskusi, praktek, dan tanya jawab. Sedangkan, materi pelatihan diberikan, yaitu pembuatan toko online di marketplace Tokopedia, pemasaran, dan manajemen. Terakhir, evaluasi pelatihan dilakukan untuk mengetahui kebermanfaatan pelatihan, kepuasan, minat, dan tindak lanjut setelah melakukan pelatihan. Evaluasi dilakukan dengan cara memberikan kuesioner sebelum dan setelah pelatihan. Hasil evaluasi ini juga digunakan oleh 
tim pengabdian masyarakat untuk mengevaluasi pelatihan. Sehingga, tim dapat mengetahui kelebihan dan kekurangan dari pelatihan yang diberikan.

\section{HASIL DAN PEMBAHASAN}

Pelaksanaan kegiatan diawali dengan pendaftaran peserta. Pada saat masa registrasi, peserta mengisi beberapa pertanyaan yang bertujuan untuk mengetahui latar belakang, pengalaman, dan pengetahuan terkait dengan jual beli online. Peserta yang mengikuti kegiatan pelatihan memiliki usia yang beragam. Hal tersebut menunjukkan antusias dari peserta untuk mengikuti pelatihan. Selain itu, materi pelatihan terkait dengan pembuatan toko daring menggunakan media aplikasi Tokopedia menjadi faktor lain peserta mengikuti pelatihan meskipun sasarannya adalah pemuda di masjid Al-Fitroh. Namun, berdasarkan pendaftaran peserta masih didominasi oleh peserta yang berusia muda.

\section{Latar Belakang Peserta Pelatihan}

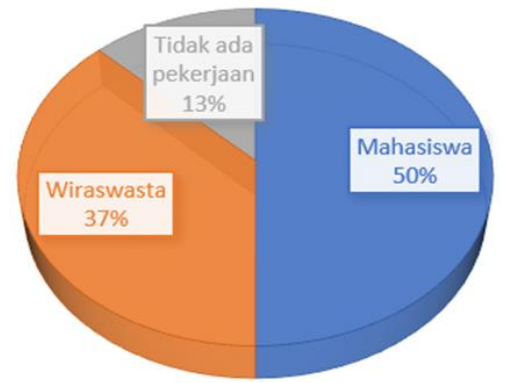

Gambar 2. Data latar belakang pekerjaan peserta pelatihan

Bervariasinya usia peserta menyebabkan materi yang disampaikan sedikit terkendala. Terutama ketika dalam pengoperasian gawai dari masingmasing peserta. Peserta dengan umur yang muda, lebih lancar dalam mengoperasikan gawai dan menyerap materi dengan mudah. Sementara itu, peserta lain memerlukan bimbingan secara khusus dan detail dalam menggunakan aplikasi Tokopedia. Selain itu, latar belakang pekerjaan peserta yang mengikuti pelatihan juga beragam. Namun, latar belakang pekerjaan sebagai mahasiswa merupakan peserta yang paling banyak mengikuti pelatihan yaitu sebanyak 50\%, seperti yang ditunjukkan pada Gambar 2 .

Berdasarkan Gambar 2, peserta pelatihan dengan latar belakang pekerjaan sebagai wiraswasta dan masih belum memiliki pekerjaan mengisi sisa peserta yang mengikuti pelatihan. Berdasarkan data yang diperoleh dari survei, peserta yang berlatar belakang sebagai mahasiswa diperoleh fakta bahwa ada yang sudah mempunyai usaha sendiri seperti, kerajinan kulit (leather craft) dan pakaian. Selain itu, peserta tersebut mengikuti pelatihan bertujuan untuk mencoba mengembangkan usaha dengan memanfaatkan marketplace untuk berjualan produk usaha mereka, termasuk untuk peserta berlatar belakang wiraswasta. 
Pengalaman Berjualan di Marketplace

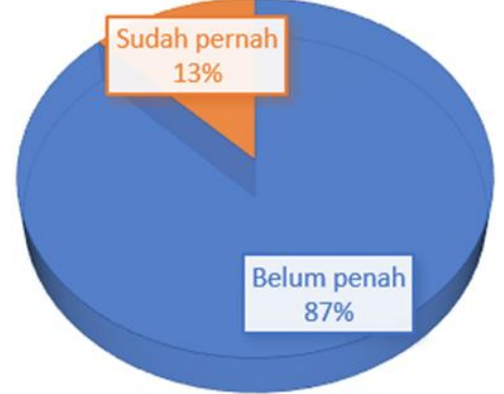

Gambar 3. Data pengalaman peserta berjualan di marketplace

\section{Pengalaman Mengikuti Pelatihan Berjualan Online di Marketplace}

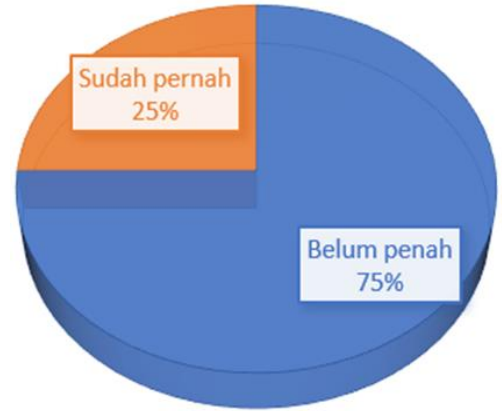

Gambar 4. Data pengalaman pengalaman mengikuti pelatihan berjualan di marketplace

Pada pelatihan ini, peserta pelatihan disurvei terkait pengalaman berjualan di marketplace. Hasil yang diperoleh berdasarkan Gambar 3 menunjukkan bahwa sebagian besar peserta tidak memiliki pengalaman menggunakan marketplace untuk berjualan, yaitu sebesar $87 \%$. Berdasarkan hasil tersebut dapat dianalisis bahwa kurangnya pengalaman berjualan dengan memanfaatkan marketplace menjadi parameter atau pemicu dari dorongan peserta dalam mengikuti pelatihan. Alasan tersebut didukung dengan hasil dari survei terkait pengalaman peserta dalam mengikuti pelatihan berjualan daring di marketplace. Gambar 4 menunjukkan bahwa sebanyak 75\% peserta belum pernah mengikuti pelatihan berjualan online di marketplace baik secara formal dan informal. Berdasarkan data yang ditunjukkan pada Gambar 4, pelatihan berjualan online ini dapat digunakan peserta untuk menggali pengalaman dan mencari tahu cara berjualan secara online dengan memanfaatkan marketplace.

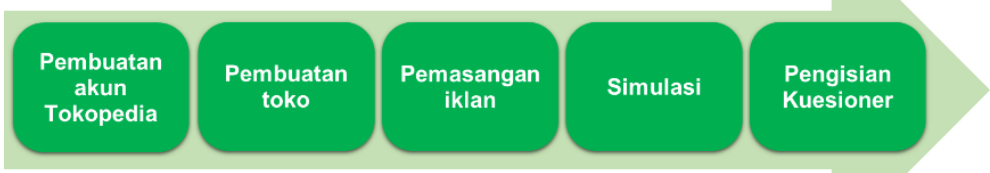

Gambar 5. Alur pelaksanaan pelatihan 


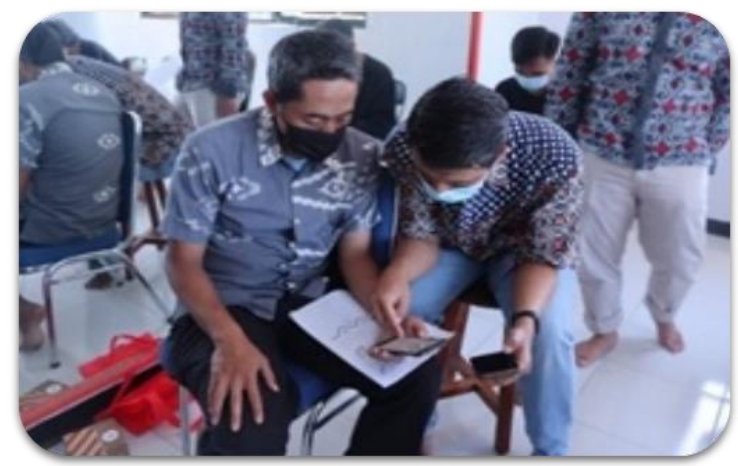

Gambar 6. Kegiatan bimbingan dari instruktur kepada peserta pelatihan

Selanjutnya, kegiatan di dalam pelatihan dilakukan dengan beberapa langkah seperti yang ditunjukkan pada Gambar 5. Pertama, peserta melakukan pembuatan akun Tokopedia sebagai penjual. Pada langkah pertama ini, peserta melakukan pendaftaran ke aplikasi Tokopedia dengan menggunakan e-mail pribadi. Kedua, peserta memulai untuk pembuatan toko sendiri. Peserta diberikan kesempatan untuk mencoba untuk memberikan nama toko sendiri, alamat, dan kelengkapan identitas toko lainnya. Ketiga, peserta memulai untuk diajarkan melakukan pemasangan iklan di toko yang sudah dibuat. Pada kegiatan ini, peserta diajarkan dan memberikan pemahaman dalam menampilkan produk yang dijual, cara mengambil gambar produk yang baik dan menarik, dan menjabarkan detail mengenai produk yang akan dijual. Keempat, peserta diberikan pendampingan dan pemahaman dengan memberikan simulasi terjadinya interaksi jual beli antara pembeli dengan penjual, berdiskusi, cara pengiriman yang baik, menyelesaikan proses jual beli, dan menarik saldo hasil transaksi jual beli. Kemudian di sesi terakhir pelatihan, peserta diminta untuk mengisi kuesioner untuk mendapatkan kepuasan, kebermanfaatan materi ke peserta, dan penilaian kepada pengajar yang mana poin-poin tersebut digunakan untuk bahan analisis dan evaluasi pelatihan.

Materi diberikan selama kegiatan pelatihan dilakukan dalam bentuk slide presentasi yang sebelumnya dijelaskan terlebih dahulu oleh instruktur dan kemudian dipraktekkan oleh peserta. Ketika kegiatan praktek berlangsung, setiap 2 peserta didampingi oleh instruktur seperti yang ditunjukkan pada Gambar 6. Peserta pelatihan dapat langsung tanya jawab dengan instruktur secara langsung sehingga materi dapat mudah dimengerti oleh peserta pelatihan. Dengan praktek langsung, diharapkan para peserta langsung mengenali cara menggunakan aplikasi marketplace Tokopedia. Sehingga setelah pelatihan, dapat ditindaklanjuti dengan aksi nyata untuk memasarkan produk-produk jualan dari peserta pelatihan. 


\section{Seberapa Banyak Materi Pelatihan yang dapat Dimengerti?}

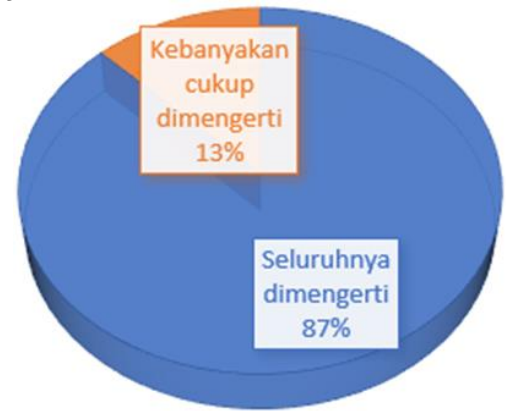

Gambar 7. Data responden terhadap penyampaian materi

Pada akhir sesi pelatihan, setiap peserta melakukan pengisian survei melalui online form yang diberikan tim panitia. Survei digunakan untuk mengetahui kinerja jalannya pelatihan atau evaluasi dan ketertarikan peserta untuk mengembangkan atau membuat usaha berbasiskan penjualan online dengan memanfaatkan marketplace. Survei pertama, peserta diminta pendapat terkait materi pelatihan yang diberikan ke peserta. Survei ini digunakan untuk mengetahui terkait materi yang diberikan dapat mudah dimengerti oleh peserta pelatihan.

Pada Gambar 7 menunjukkan bahwa materi yang diberikan dapat mudah dimengerti oleh peserta pelatihan dengan porsi nilai $87 \%$. Pelaksanaan pelatihan dengan model presentasi yang langsung diikuti dengan praktik mampu membuat peserta bersemangat untuk menggali lebih detil tentang penggunaan aplikasi Tokopedia. Hal ini turut membantu percepatan pemahaman para peserta, dan setelah pelatihan instruktur secara aktif tetap menanggapi berbagai pertanyaan teknis dari para peserta.

\section{Apakah Pelatihan yang Dilaksanakan Bermanfaat?}

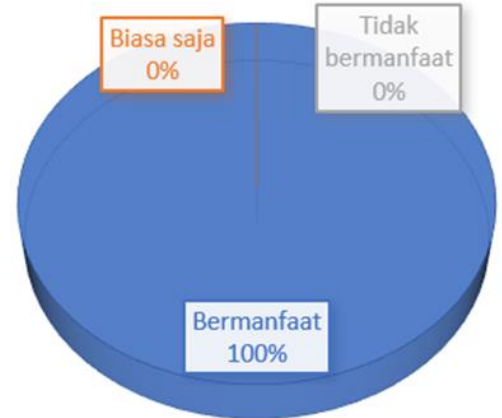

Gambar 8. Data responden terhadap manfaat terhadap peserta pelatihan 
Setelah Pelatihan ini Apakah Anda Tertarik untuk Berjualan Online?

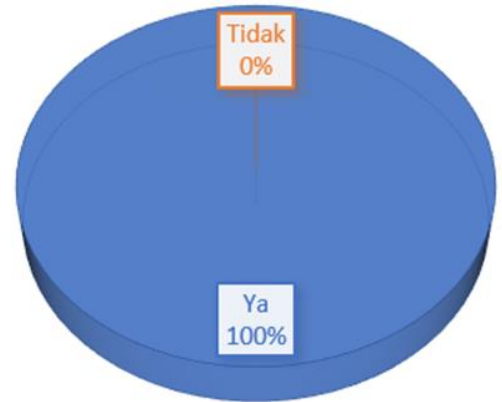

Gambar 9. Data ketertarikan peserta untuk berjualan online

Kemudian terkait dengan manfaat dari pelatihan, Gambar 8 menunjukkan hasil penilaian manfaat materi yang diberikan dalam pelatihan kepada peserta yang mana menunjukkan penilaian $100 \%$. Penilaian tersebut menunjukkan bahwa pelatihan sangat bermanfaat bagi peserta dan dapat diterapkan oleh peserta pelatihan. Manfaat yang diperoleh peserta dalam mengikuti pelatihan menunjukkan bahwa pelatihan memberikan dampak pada ketertarikan peserta untuk berjualan secara online. Hasil survei menunjukkan bahwa secara keseluruhan seluruh peserta atau $100 \%$ peserta memiliki ketertarikan yang sangat untuk berjualan online, seperti yang ditunjukkan pada Gambar 9. Selain itu, hasil tersebut didukung dengan hasil survei terkait dengan pelatihan lanjutan yang digunakan untuk mengawasi kemajuan toko yang telah dibuat oleh peserta.

\section{Apakah Diperlukan Pelatihan Berjualan Online yang lebih Mendalam?}

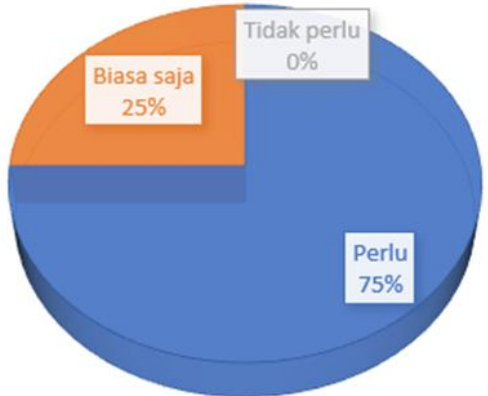

Gambar 10. Data responden terhadap diperlukannya pelatihan berjualan online yang lebih mendalam

Gambar 10 menunjukkan bahwa peserta membutuhkan pendampingan lebih lanjut setelah mengikuti pelatihan. Sebanyak $75 \%$ peserta memberikan pendapat untuk perlu diadakan pelatihan lanjut berjualan online dengan memanfaatkan marketplace. Hasil tersebut menunjukkan bahwa peserta benarbenar ingin memperdalam dan ingin mengetahui potensi berjualan suatu produk mereka dengan memanfaatkan marketplace. Selain itu, peserta dapat ditargetkan menata atau mengatur tampilan produk yang dijual dengan baik serta dapat meningkatkan pelayanan toko mereka. Dengan pendampingan balik ini, kegiatan pengabdian masyarakat tidak terhenti sampai dengan 
pelaksanaan pelatihan saja. Peserta-peserta yang memiliki minat besar untuk menindaklanjuti hasil pelatihan secara serius dapat dipandu untuk mempercepat penguasaan pengoperasian fitur-fitur penting pada aplikasi Tokopedia. Fitur-fitur penting seperti membuat tampilan foto yang eye catching, menambahkan deskripsi produk yang mempermudah calon pembeli mengetahui detil produk, hingga bagaimana memanfaatkan promosi-promosi agar kunjungan calon pembeli meningkat signifikan.

Berdasarkan hasil survei yang diperoleh, pelatihan yang dilaksanakan telah memberikan manfaat bagi peserta dan menumbuhkan ketertarikan untuk membangun usaha dan mengembangkan usaha secara online dengan memanfaatkan marketplace yang tersedia. Selain itu, hasil tersebut dapat menunjukkan minat peserta untuk mencoba beradaptasi dengan kondisi pandemi Covid-19 ini yang tidak bisa berjualan secara normal dan memiliki potensi untuk menghasilkan pengusaha baru yang memulai usaha melalui marketplace yang tersedia.

\section{KESIMPULAN}

Pelatihan yang diadakan untuk mengembangkan usaha sangat penting di masa pandemi Covid-19 ini. Sehingga, pelatihan ini memberikan harapan dan solusi bagi masyarakat yang kebingungan untuk tetap mencari penghasilan dan mempertahankan usaha yang sudah dibangun agar tetap berdiri. Hasil dari survei menunjukkan bahwa peserta mendapatkan manfaat dari pelatihan ini dan memiliki ketertarikan untuk membangun usaha atau mengembangkan usaha secara online. Sehingga, peserta dapat beradaptasi dengan kondisi pandemi Covid-19 ini yang tidak bisa berjualan secara normal. Selain itu, pelatihan ini memiliki potensi untuk menghasilkan pengusaha baru yang memulai usaha melalui marketplace yang tersedia. Namun, pelatihan ini perlu dikembangkan karena perlu pendampingan lebih lanjut agar peserta dapat dibimbing hingga mampu mengembangkan usaha online secara mandiri dan lebih baik. Kebutuhan pendampingan memang diperlukan oleh peserta dengan dibuktikan berdasarkan hasil dari survei sebanyak $75 \%$.

Pendampingan kepada peserta pelatihan menjadi hal yang krusial dalam menjamin keberlanjutan hasil pelatihan yang diberikan. Berdasarkan pengalaman yang telah dicoba para instruktur sebelum pelatihan diberikan, dapat disimpulkan bahwa dibutuhkan inisiatif yang besar dari setiap peserta untuk terus menggali fitur-fitur yang ada pada aplikasi marketplace Tokopedia. Dengan semakin sering mengoperasikan dan mencoba berbagai fitur yang ada, akan terbentuk intuisi yang makin kuat dalam mengoperasikan toko online. Hal penting lainnya adalah peserta perlu didorong untuk memanfaatkan data-data statistik yang menunjukkan pencapaian kinerja toko online, sehingga dapat mendorong semangat pemilik toko online untuk memperbaiki secara terusmenerus tampilan produk, deskripsi, dan hal lain terkait informasi produk.

\section{UCAPAN TERIMA KASIH}

Ucapan terima kasih kami ucapkan kepada Telkom University telah memberikan pendanaan sehingga terlaksananya pengabdian masyarakat ini. 


\section{DAFTAR RUJUKAN}

Arrizal, N. Z., \& Sofyantoro, S. (2020). Pemberdayaan Ekonomi Kreatif dan UMKM di Masa Pandemi Melalui Digitalisasi. Birokrasi Pancasila: Jurnal Pemerintahan, Pembangunan Dan Inovasi Daerah, 2(1), 39-48. https://mail.jurnal.madiunkab.go.id/index.php/bp/article/view/48

Awali, H. (2020). Urgensi Pemanfaatan E-Marketing Pada Keberlangsungan Umkm Di Kota Pekalongan Di Tengah Dampak Covid-19. BALANCA: Jurnal Ekonomi Dan Bisnis Islam, 2(1), 1-14. https://doi.org/10.35905/balanca.v2i1.1342

Azizah, F. N., Ilham, I. F., Aqidah, L. P., Firdaus, S. A., Astuti, S. A. D., \& Buchori, I. (2020). Strategi UMKM untuk Meningkatkan Perekonomian selama Pandemi Covid-19 pada saat New Normal. OECONOMICUS Journal of Economics, 5(1), 46-62. https://doi.org/10.15642/oje.2020.5.1.46-62

Barri, M. H., Rizal, A., Cahyadi, W. A., Hidayat, I., Pramudita, B. A., \& Prihatiningrum, N. (2021). Pelatihan E-Commerce Bagi Warung Sedekah (Warkah) Untuk Meningkatkan Pertumbuhan Ekonomi Rumah Tangga. KACANEGARA Jurnal Pengabdian Pada Masyarakat, 4(1), 83. https://doi.org/10.28989/kacanegara.v4i1.821

Desiani, A., Putri, A. I., Yuniar, E., Calista, A., Makhalli, S., \& Amran, A. (2021). Pemanfaatan marketplace shopee sebagai meningkatkan pemasaran kain songket. Jurnal Inovasi Hasil Pengabdian Masyarakat (JIPEMAS), 4(2), 209-219. https://doi.org/10.33474/jipemas.v4i2.9222

Diana, \& Laila, N. (2020). Strategi Pengembangan Usaha Home Industri Makanan Sebagai Peluang Pendapatan di Masa Pandemi Covid-19. Prosiding Seminar Nasional Pengabdian Masyarakat LPPM UMJ, 1(1), 1-8.

Istiatin, \& Marwati, F. S. (2021). Sosialisasi Berbagai Peluang Usaha UMKM dan Ekonomi Kreatif di Era New Normal di Dusun Pinggir Desa Telukan Sukoharjo. Budimas: Jurnal Pengabdian Masyarakat, 3(1), 129-140. https://doi.org/10.29040/budimas.v3i1.2027

Jalil, A., M, F., \& Kasnelly, S. (2020). Meningkatnya Angka Pengangguran Di Tengah Pandemi (Covid-19). Al-Mizan: Jurnal Ekonomi Syariah, 3(1), 4560.

https://doi.org/https://ejournal.annadwah.ac.id/index.php/almizan/article/view/142

Kala'lembang, A. (2017). Adopsi E-Commerce Dalam Mendukung Perkembangan Usaha Mikro Kecil dan Menengah (UMKM) di Masa Pandemi Covid-19. Jurnal Ekonomi Dan Manajemen, 14(2), 66-79. 10.25273/capital.v4i1.7358\%0A

Mubarrok, U. S., Fajariah, N., \& Yani, A. (2021). Fasilitasi peningkatan kompetensi wirausaha kuliner di era pandemi. Jurnal Inovasi Hasil Pengabdian Masyarakat (JIPEMAS), 4(2), 190-198. https://doi.org/10.33474/jipemas.v4i2.9249

Perdamaian, P. D., Puspita, A., \& Frida, N. (2020). Analisis Strategi Mempertahankan dan Mengembangkan Bisnis di Tengah Pandemi COVID-19 Serta Mengetahui Dampak Perkembangan dan Pertumbuhan 
COVID-19 di Indonesia. Jurnal Aktiva: Riset Akuntansi Dan Keuangan, 2(3), 28-36. 10.52005/aktiva.v2i3.61

Rosita, R. (2020). Pengaruh Pandemi Covid-19 Terhadap UMKM di Indonesia. Jurnal Lentera Bisnis, 9(2), 109-120. https://doi.org/10.34127/jrlab.v9i2.380

Taryudi, A., Maulana, D., Hafifah, H., Kistia, J., \& ... (2021). Pemulihan Ekonomi Keluarga UMKM Lokal melalui Pelatihan Desain Kemasan Produk dan Pemasaran Online di Desa Pekandangan Jaya, Kabupaten Indramayu. Jurnal Pusat Inovasi Masyarakat (PIM), 3(1), 27-35. https://journal.ipb.ac.id/index.php/pim/article/view/35346

Zebua, D. D. N., \& Sunaryanto, L. T. (2021). Platform Digital Sebagai Alternatif Bertahan Di Era Pandemi Covid-19 Bagi Pelaku Bisnis Pertanian. Mimbar Agribisnis: Jurnal Pemikiran Masyarakat Ilmiah Berwawasan Agribisnis, 7(1), 848. https://doi.org/10.25157/ma.v7i1.4834 